\title{
Biochemical partitioning of photosynthetically fixed carbon by benthic diatoms during short-term incubations at different irradiances
}

\author{
K. Wolfstein*, J. F. C. de Brouwer, L. J. Stal \\ Netherlands Institute of Ecology, Centre for Estuarine and Coastal Ecology, PO Box 140, 4400 AC Yerseke, The Netherlands
}

\begin{abstract}
The partitioning of photosynthetically fixed carbon (C) into different fractions of intracellular and extracellular C pools by an axenic culture of Cylindrotheca closterium (Ehrenberg) and a field sample of natural benthic diatoms was studied using short-term incubation with ${ }^{14} \mathrm{C}$ at different irradiances. Hence, excretion was directly dependent on the level of irradiance. During the incubations, a comparable amount of about 70 and $75 \%$ of the fixed C, respectively, was excreted by the culture and the field sample. This excreted $\mathrm{C}$ was distinguished in 2 operational fractions of attached (closely bound to the cells) and colloidal (soluble) material. In the field sample, the percentage of excreted $\mathrm{C}$ decreased at irradiances higher than $300 \mu \mathrm{mol}$ photons $\mathrm{m}^{-2} \mathrm{~s}^{-1}$, but it was constant for the culture over the whole range of different irradiances applied. The percentage of extracellular polymeric substances (EPS) in the attached and colloidal material, as obtained by ethanol precipitation, was constant over the range of the provided irradiances for both samples. Subsamples of natural benthic diatoms were treated with an antibiotic cocktail in order to exclude bacterial activity which resulted in unexpected higher values of incorporated $\mathrm{C}$ in the fractions of total $\mathrm{C}$, intracellular $\mathrm{C}$, colloidal $\mathrm{C}$ and EPS.
\end{abstract}

KEY WORDS: Cylindrotheca closterium - Extracellular polymeric substances $\cdot$ Microphytobenthos · P/E curves $\cdot$ Photosynthesis

\section{INTRODUCTION}

The benthic microalgal community of cohesive sediments often consists of a large number of epipelic diatoms (Underwood 1994, Underwood \& Kromkamp 1999). These diatoms are known to excrete highly hydrated, carbohydrate-rich substances. During the stationary phase, up to $50 \%$ of the material may consist of extracellular polymeric substances (EPS) (Smith \& Underwood 2000). These exopolymers are of importance for these algae as they are involved in various processes, such as capturing of nutrients, motility and protection against desiccation (Decho 1990, Hoagland

\footnotetext{
${ }^{*}$ Present address: Institute for Inland Water Management and Waste Water Treatment (RIZA), PO Box 17, 8200 AA Lelystad, The Netherlands. Email: k.wolfstein@riza.rws.minvenw.nl
}

et al. 1993). They also play a role in sediment stabilisation (Paterson 1989) and enter the food web as a source of organic matter for bacteria or grazers (Decho 1990, Smith \& Underwood 1998, Van Duyl et al. 1999). Due to the importance of these substances, several studies have focussed on their characterisation, quantification and/or identification of the factors which control their production, such as nutrients (Sutherland et al. 1998, Staats et al. 2000a) or irradiance (Smith \& Underwood 1998, Staats et al 2000b). A direct relationship between the production of exopolymers and oxygenic photosynthesis was found by Staats et al. (2000b), but they did not investigate the effect of different light intensities on their production. However, different light intensities may have direct consequences on the amount of EPS produced during different seasons. Seasonal variation in extracellular carbohydrates on an intertidal mudflat was studied by De Brouwer et al. (2000), but 
these authors did not relate their observations to changes in irradiance.

The objective of our study was to investigate the effect of different irradiances on the quantity of exopolymer production and on the short-term partitioning of the photosynthetically fixed carbon (C) into different intra- and extracellular fractions. Results from laboratory cultures are difficult to translate to the field. Therefore, we applied similar methods to isolate the various $\mathrm{C}$ fractions in a Cylindrotheca closterium culture and in a natural microphytobenthic community, freshly collected from a nearby mudflat in the Westerschelde estuary (The Netherlands). In this way, it was possible to compare the excretion of photosynthetically fixed $\mathrm{C}$ in the culture and in the field sample. The latter contained bacteria while this was not the case in the benthic diatom culture. Bacteria may influence the dynamics of extracellular substances in various ways. They are able to produce EPS themselves (Decho 1990) and may degrade exopolymers (Goto et al. 2001). Therefore, the effect of bacteria on the dynamics of extracellular substances was studied by using antibiotics which inhibited the bacterial activity.

\section{MATERIALS AND METHODS}

Culture conditions and sampling. An axenic strain of Cylindrotheca closterium (Ehrenberg), which was isolated from the Ems Dollard, The Netherlands, was used for the experiments. Cells were grown at $15^{\circ} \mathrm{C}$ in $\mathrm{f} / 2$ medium which was modified as described in Table 1 , at an incident photon irradiance of $100 \mu \mathrm{mol} \mathrm{m} \mathrm{m}^{-2} \mathrm{~s}^{-1}$ provided by Philips TLD 15W/840 fluorescent tubes,

Table 1. Composition of the artificial seawater medium for Cylindrotheca closterium

\begin{tabular}{|c|c|c|c|}
\hline Component & $\begin{array}{c}\text { Concentration } \\
\left(\mathrm{g} \mathrm{l}^{-1}\right)\end{array}$ & Component & $\begin{array}{c}\text { Concentration } \\
\left(\mathrm{g} \mathrm{l}^{-1}\right)\end{array}$ \\
\hline $\mathrm{NaCl}$ & 24.1 & Trace metal mix & \\
\hline $\mathrm{Na}_{2} \mathrm{SO}_{4}$ & 32 & $\mathrm{CuSO}_{4} \cdot 5 \mathrm{H}_{2} \mathrm{O}$ & $9.8 \times 10^{-6}$ \\
\hline $\mathrm{MgCl}_{2} \cdot 6 \mathrm{H}_{2} \mathrm{O}$ & 8.7 & $\mathrm{ZnSO}_{4} \cdot 7 \mathrm{H}_{2} \mathrm{O}$ & $22 \times 10^{-6}$ \\
\hline $\mathrm{KCl}$ & 0.54 & $\mathrm{CoCl}_{2} \cdot 6 \mathrm{H}_{2} \mathrm{O}$ & $10 \times 10^{-6}$ \\
\hline $\mathrm{CaCl}_{2} \cdot 2 \mathrm{H}_{2} \mathrm{O}$ & 1.6 & $\mathrm{MnCl}_{2} \cdot 4 \mathrm{H}_{2} \mathrm{O}$ & $18 \times 10^{-6}$ \\
\hline $\mathrm{NaHCO}_{3}$ & 0.18 & $\mathrm{Na}_{2} \mathrm{MoO}_{4} \cdot 4 \mathrm{H}_{2} \mathrm{O}$ & $6.3 \times 10^{-6}$ \\
\hline $\mathrm{KBr}$ & 0.039 & & \\
\hline $\mathrm{NH}_{4} \mathrm{Cl}$ & 0.0268 & Vitamın mix & \\
\hline $\mathrm{H}_{3} \mathrm{BO}_{3}$ & 0.011 & Blotin & \\
\hline $\mathrm{NaH}_{2} \mathrm{PO}_{4} \cdot \mathrm{H}_{2} \mathrm{O}$ & 0.0069 & I hlamine-HCl & $\begin{array}{l}2 \times 10^{-5} \\
8 \times 10^{-7}\end{array}$ \\
\hline $\mathrm{SrCl}_{2} \cdot 6 \mathrm{H}_{2} \mathrm{O}$ & 0.010 & Cyanocobalamin & $\begin{array}{l}8 \times 10^{-t} \\
8 \times 10^{-8}\end{array}$ \\
\hline $\mathrm{NaSiO}_{3} \cdot 9 \mathrm{H}_{2} \mathrm{O}$ & 0.0426 & Folic acid & $8 \times 10^{-8}$ \\
\hline $\mathrm{Na} 2 \mathrm{SeO}_{3} \cdot 5 \mathrm{H}_{2} \mathrm{O}$ & $1.6 \times 10^{-9}$ & $\begin{array}{l}\text { Nicotinic acid } \\
\text { Thymine }\end{array}$ & $\begin{array}{r}4 \times 10^{-6} \\
1.2 \times 10^{-4}\end{array}$ \\
\hline Citrate mix & & Ca-d-pantothenate & $4 \times 10^{-6}$ \\
\hline $\mathrm{C}_{6} \mathrm{H}_{8} \mathrm{O}_{7} \cdot \mathrm{H}_{2} \mathrm{O}$ & 0.003 & Inositol & $2 \times 10^{-4}$ \\
\hline $\mathrm{Fe}-\mathrm{NH}_{4}$-citrate & 0.00036 & & \\
\hline
\end{tabular}

supplied on a 12:12 h light:dark cycle. The algae were cultured in $1 \mathrm{l}$ glass Erlenmeyer flasks in which the bottom was covered with purified sea sand (Merck). The cultures were subsampled at the end of the exponential/early stationary growth phase (Days 9 and 10, respectively) when growth decreased. Prior to sampling, the culture was gently shaken until all cells were suspended, and subsequently, the sand was allowed to settle before a sample of the algal suspension was taken.

One d before the experiment started, a natural population of benthic diatoms was sampled by scraping off the surface layer of sediment from the sampling site 'Biezelingse Ham' at the Westerschelde, The Netherlands $\left(51^{\circ} 26^{\prime} 47^{\prime \prime} \mathrm{N}, 3^{\circ} 55^{\prime} 51^{\prime \prime} \mathrm{E}\right)$ at ebb tide. The sample was put in a jar, and the sediment with the algae was covered with 3 layers of lens tissue (Whatman) and incubated for several hours at an irradiance of $100 \mu \mathrm{mol} \mathrm{m} \mathrm{m}^{-2} \mathrm{~s}^{-1}$. The motile algae migrated through the tissue to the surface and were harvested by removing the upper layer of tissue. The algae were suspended in $\mathrm{f} / 2$ medium, and kept at $15^{\circ} \mathrm{C}$ and $100 \mu \mathrm{mol}$ $\mathrm{m}^{-2} \mathrm{~s}^{-1}$ until the experiments started.

Subsamples of the culture and the field sample were stained with Sybergreen (Weinbauer et al. 1998) and microscopically studied in order to check axenity of the cultures and to count bacteria in the field sample. Dominant species of benthic diatoms that migrated through the lens tissue were identified by light microscopy after their organic cell compounds were removed by a treatment with sulphuric acid, potassium permanganate and oxalic acid (Hasle \& Fryxell 1970).

Experimental set-up. At the start of each experiment, subsamples were taken for chlorophyll a (chl a) analysis ( $\mathrm{n}=3$ ). A volume of $15 \mathrm{ml}$ of the algal suspension was centrifuged for $10 \mathrm{~min}$ at $3500 \times g$ with a Sigma $4 \mathrm{~K} 15$ centrifuge. Chl a was extracted from the cell pellet using $5 \mathrm{ml}$ of $96 \%$ acetone and the extract was subsequently measured with an Ultraspec 4000 spectrophotometer (Jeffrey \& Humphrey 1975).

The effect of irradiance on the partitioning of photosynthetically fixed $\mathrm{C}$ by Cylindrotheca closterium and a field sample was investigated by means of short-term incubations (30 min) with ${ }^{14} \mathrm{C}$. Three replicate measurements were performed for both the culture and the field samples. However, for technical reasons, the measurements were carried out with subsamples from the original culture and field sample over 3 different days. 
For every single incubation, $15 \mathrm{ml}$ of the algal suspension was transferred to the cuvette of a DW3 oxygen chamber (Hansatech). To this sample, $400 \mu \mathrm{l}$ of $\mathrm{NaH}^{14} \mathrm{CO}_{3}$ (Amersham, final activity of $370 \mathrm{KBq}$ sam$\mathrm{ple}^{-1}$ ) was added. The suspension was well mixed by a magnetic stirrer situated at the bottom of the cuvette. The samples were kept in the dark for 5 min and subsequently exposed to various irradiances for a period of $30 \mathrm{~min}$. Temperature was kept constant at $15 \pm 1^{\circ} \mathrm{C}$. Nine measurements at different irradiances $(5,19,37$, $47,87,159,333,733$ and $\left.1260 \mu \mathrm{mol} \mathrm{m}^{-2} \mathrm{~s}^{-1}\right)$, randomly placed over the whole day, were performed. A dark (heterotrophic uptake) and a poisoned (glutaraldehyde of $3 \%$ final concentration; passive/abiotic uptake) control were taken. The incubations were stopped by adding glutaraldehyde (3\% final concentration) to each subsample. After the different fractionation steps (described below), the non-incorporated $\mathrm{C}$ was removed from each sample by adding $100 \mu$ l of concentrated $\mathrm{HCl}$, as proved by the control incubations. Dissolved inorganic $\mathrm{C}$ in the medium was determined by potentiometric titration (Parsons et al. 1984). Packard scintillation cocktail was added to each subsample and ${ }^{14} \mathrm{C}$ incorporation was measured with a Packard Tri-Carb 2300 TR scintillation counter, including an automatic quench correction.

For each incubation, incident and outcoming irradiance was measured with a LICOR quantum sensor Q19736 connected to a LI-1000 data logger. Mean values $(E)$ of the incident $\left(E_{0}\right)$ and the irradiance coming out of the cuvette $\left(E_{\mathrm{z}}\right)$ were calculated according to the formula of Van Liere \& Walsby (1982):

$$
E=\frac{E_{0}-E_{z}}{\ln E_{0}-\ln E_{z}}
$$

Photosynthetic efficiency $\left(\alpha^{\mathrm{B}}\right)$, maximum photosynthetic rate $\left(P_{\max }^{\mathrm{B}}\right)$ and the light saturation parameter $\left(E_{\mathrm{k}}\right)$ were calculated using the fit of Walsby (1997). The superscripted B indicates that photosynthetic parameters are expressed $\mathrm{mg}^{-1} \mathrm{chl}$ a.

Algal $\mathrm{C}$ of the suspension was calculated by using a C:chl a ratio of 50 (De Jonge 1980). To calculate bacterial C, a C conversion factor of $2.0 \times 10^{-14} \mathrm{gC} \mathrm{cell}^{-1}$ (Lee \& Fuhrman 1987) was used.

Fractionation of the different pools of carbon. The different fractions of carbon were obtained according to Fig. 1: total fixed C (sum of intracellular, colloidal and attached extracellular C), intracellular C, colloidal $\mathrm{C}$ and EPS, attached $\mathrm{C}$ and attached EPS, and glucans. After incubation with $\mathrm{NaH}^{14} \mathrm{CO}_{3}$ the algal suspension was divided into 2 subsamples which both were centrifuged at $5310 \times g$ for $10 \mathrm{~min}$. The supernatant contained all colloidal (soluble) extracellular $\mathrm{C}$. The cell pellet was extracted with distilled water $\left(1 \mathrm{~h}, 30^{\circ} \mathrm{C}\right)$ and subsequently centrifuged in order to obtain the attached (bound to the cells) extracellular C which was present in the supernatant (Staats et al. 2000b). The high molecular part of both fractions (termed 'attached' and 'colloidal EPS') was obtained by the addition of $96 \%$ ethanol (final concentration of $75 \%$ ) and subse-

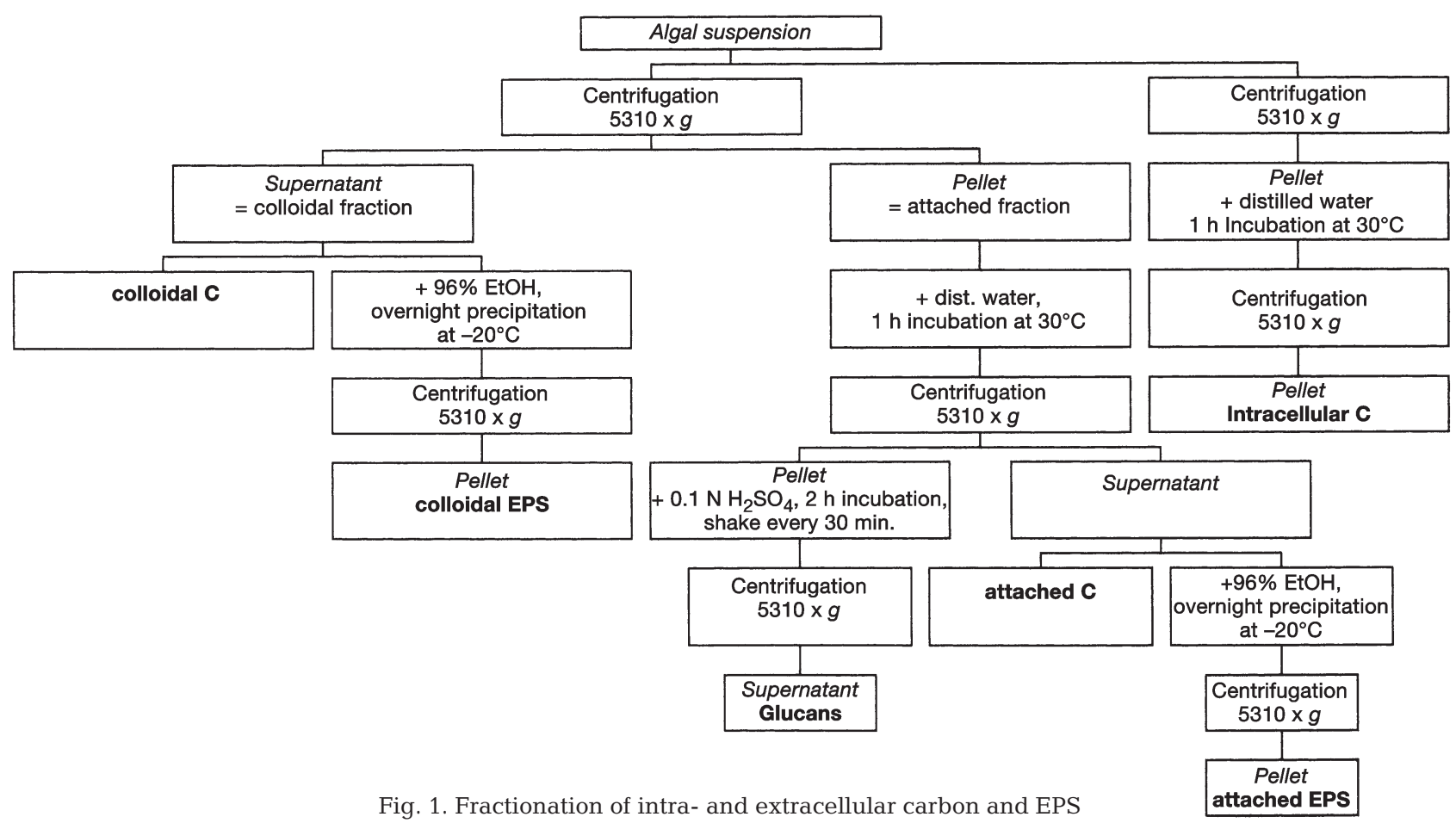


quent overnight precipitation at $-20^{\circ} \mathrm{C}$. The remaining pellet after the extraction of the attached and colloidal $\mathrm{C}$ was incubated for $2 \mathrm{~h}$ in $0.1 \mathrm{~N} \mathrm{H}_{2} \mathrm{SO}_{4}$ in order to obtain storage glucans (Smith \& Underwood 1998). The cell pellet of the second subsample of the initial algal suspension (after extraction of the attached and colloidal C) was considered as the fraction of intracellular C. Finally, the ${ }^{14} \mathrm{C}$ content of all fractions was measured.

Effect of bacteria. A second experiment was carried out to assess the effect of bacteria on the partitioning of photosynthetically fixed $\mathrm{C}$ of the field samples. To inhibit bacterial activity, a cocktail of antibiotics (final concentration of $125 \mu \mathrm{g} \mathrm{ml} \mathrm{m}^{-1}$ benzylpenicillin and $25 \mu \mathrm{g} \mathrm{ml}^{-1}$ streptomycin sulfate) was added to a subsample of the benthic diatom population $2 \mathrm{~h}$ before the experiment was started. A photosynthetron (Lewis \& Smith 1983) was used to simultaneously incubate the samples with antibiotics $(\mathrm{n}=2)$ and a control (without the addition of antibiotics, $\mathrm{n}=1$ ) at 9 different irradiances $(7,23,39,84,173,322,903,1303$ and $1903 \mu \mathrm{mol}$ $\mathrm{m}^{-2} \mathrm{~s}^{-1}$ ) at $15 \pm 1^{\circ} \mathrm{C}$. To check the inhibitory effect of the antibiotics, $\mathrm{D}^{14} \mathrm{C}$-glucose $\left(12.3 \mathrm{KBq} \mathrm{ml}{ }^{-1}\right)$ was added to another set of samples. After the incubation, the samples were processed as described above.

Statistical analyses. One-way ANOVA and Spearman's rank correlation was used in order to test whether values differed significantly from each other and to assess the relationships between single parameters. All statistical analyses were performed using the software program Statistica 5.1.

\section{RESULTS}

\section{Comparison between the laboratory culture and the field sample}

To compare the production of extracellular material between the field samples and the culture, values were normalised to chl $a$. The content of chl a of the Cylindrotheca closterium culture and in the field samples were 1.66 to 1.91 and 2.28 to $3.75 \mu \mathrm{g} \mathrm{ml}^{-1}$, respectively. Microscopic examination revealed that the C. Closterium culture was free of bacteria, whereas in the field samples $5.3 \times 10^{5}$ bacteria $\mathrm{ml}^{-1}$ were counted. The dominant diatom species in the field samples was Navicula phyllepta. Other species of the genera Amphora, Navicula, Nitzschia, Raphoneis and Surirella were present.

Photosynthetic parameters showed higher values in the field samples of 'natural' microphytobenthos compared to the Cylindrotheca closterium culture (Table 2): $P_{\text {max }}^{\mathrm{B}}$ of total fixed $\mathrm{C}$ was about 2.5 times higher, but the distinction in other photosynthetic parameters was
Table 2. Photosynthetic parameters of Cylindrotheca closterium and the field samples

\begin{tabular}{|c|c|c|}
\hline Parameters & C. closterium & Field sample \\
\hline$P_{\text {max }}^{\mathrm{B}}$ & $1.15 \pm 0.34$ & $2.97 \pm 0.56$ \\
\hline$\alpha^{\mathrm{B}} \quad \mathrm{b}$ & $0.02 \pm 0.01$ & $0.04 \pm 0.003$ \\
\hline & $61.99 \pm 22.19$ & $74.17 \pm 29.57$ \\
\hline \multicolumn{3}{|c|}{$\begin{array}{l}P^{\mathrm{B}} \max \text { is the maximum photosynthetic rate expressed per } \\
\text { chlorophyll } a(\mathrm{chl} a), \alpha^{\mathrm{B}} \text { the photosynthetic efficiency nor- } \\
\text { malised to chl } a \text {, and } E_{\mathrm{k}} \text { the light saturation parameter } \\
{ }^{\mathrm{a}} \mathrm{mgC}(\mathrm{mg} \mathrm{chl} a)^{-1} \mathrm{~h}^{-1} \\
{ }^{\mathrm{b}} \mathrm{mgC}(\mathrm{mg} \operatorname{chl} a)^{-1} \mathrm{~h}^{-1}\left(\mu \mathrm{mol} \text { photons } \mathrm{m}^{-2} \mathrm{~s}^{-1}\right)^{-1} \\
{ }^{\mathrm{c}} \mu \mathrm{mol} \text { photons } \mathrm{m}^{-2} \mathrm{~s}^{-1}\end{array}$} \\
\hline
\end{tabular}

less pronounced. The values varied between 0.74 and 1.43 for C. closterium, and between 2.07 and 3.52 for the field sample. No trend in photosynthetic parameters, neither increase nor decrease, was observed in the measurements over the $3 \mathrm{~d}$.

There were no proportional differences in the amounts of intracellular and total extracellular $\mathrm{C}$ between the Cylindrotheca closterium culture and the field samples of benthic diatoms. However, a large difference was observed in the amounts of the colloidal and attached $\mathrm{C}$ fractions (Fig. 2). The amount of colloidal $\mathrm{C}$ was much higher in the field sample than in the culture, while the opposite was true for the fraction of attached C. C. closterium and the field sample excreted on average 70 and $75 \%$ of all fixed $C$, respectively, even at low irradiances $\left(\geq 5 \mu \mathrm{mol}\right.$ photons $\mathrm{m}^{-2}$ $\mathrm{s}^{-1}$ ). The relative amounts of photosynthetically fixed $\mathrm{C}$ that were excreted did not vary to a large extent over the range of irradiances measured. It was constant for C. closterium, while-surprisingly - in the field samples somewhat lower relative amounts were excreted at the 3 highest irradiances $(F=3.58, \mathrm{p}<0.05)$.

In the field samples, the percentage of EPS of extracellular $\mathrm{C}$ was higher than in the culture; mean col-

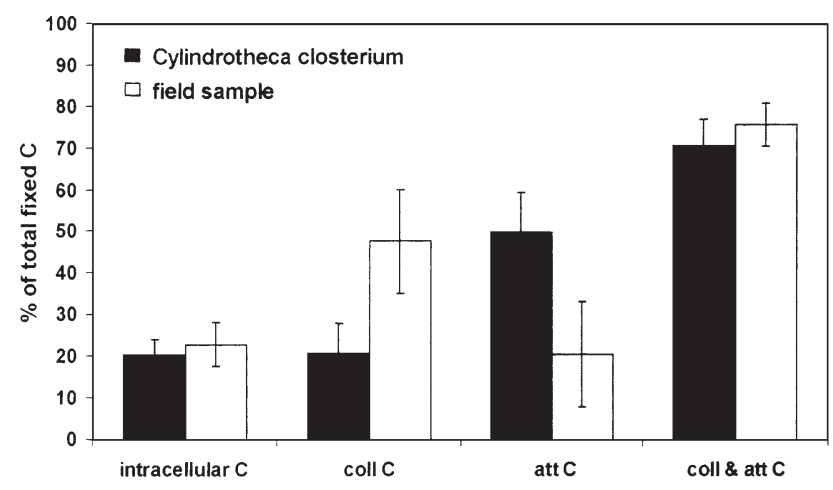

Fig. 2. Percentage of total fixed intra- and extracellular carbon in a Cylindrotheca closterium culture and in a field sample of microphytobenthos 
loidal EPS was $33 \pm 4 \%$ of total colloidal $\mathrm{C}$ and mean attached EPS was $28 \pm 7 \%$ of total attached C compared to, respectively, $21 \pm 7$ and $17 \pm 14 \%$ for $C y l i n-$ drotheca closterium. The percentages of colloidal and attached EPS (of total colloidal $\mathrm{C}$ and attached $\mathrm{C}$, respectively) was constant over the range of different irradiances measured. This was true for both $C$. closterium and the field sample.

A constant percentage of $21 \%$ of total fixed $\mathrm{C}$ was recovered in intracellular compounds (including structural cell material) of the Cylindrotheca closterium culture. In the field samples, the average percentage of intracellular C was $23 \%$, but in contrast to the culture, it increased with increasing irradiances $(F=3.36$, $\mathrm{p} \leq 0.05)$. The relative amounts of intracellular $\mathrm{C}$ were comparable between the culture and the field samples (Fig. 2), but the average percentages of the glucan fraction showed larger differences between both samples (average of $9 \%$ of total fixed $\mathrm{C}$ in C. closterium and $2 \%$ in the field sample).

Light-response curves for the different $\mathrm{C}$ fractions are shown in Fig. 3 (Cylindrotheca closterium and field samples, respectively). They were recorded in order to examine the relationship between irradiance and the amount of incorporated or excreted C. Mean values of each fraction, the range between the single measurements (between the 3 replicates) and the calculated fits of the mean values are plotted in separate panels. In the field samples, higher values were measured for all fractions with the exception of the glucan fraction, but the results showed considerable variation. The values of the culture and the field samples overlapped within the fractions of attached $\mathrm{C}$ and EPS, colloidal $\mathrm{C}$ and glucans. In both samples, the total amount of fixed $\mathrm{C}$ increased with increasing irradiances, and the 'fits' showed saturation at ca. $300 \mu \mathrm{mol} \mathrm{m} \mathrm{m}^{-2} \mathrm{~s}^{-1}$ (Fig. 3A). In the light saturated part of the curve, mean values of $\mathrm{C}$ fixation were constant for $C$. closterium. No trend could be observed for the field samples because the values showed too much variation. In both samples, the curves of intracellular C fraction (Fig. 3B) showed a similar pattern compared to total $\mathrm{C}$. This was also the case for the fraction of attached C (Fig. 3D). Compared to the other curves, differences between these 2 curves were smaller or not significant, because of variation of the data. The colloidal $\mathrm{C}$ fraction (Fig. 3C) increased up to an irradiance of $300 \mu \mathrm{mol} \mathrm{m} \mathrm{m}^{-2} \mathrm{~s}^{-1}$ and showed a concomitant decrease at higher irradiances in both samples. The fits of colloidal EPS (Fig. 3E) showed the same pattern as colloidal $\mathrm{C}$ for both samples, values increased until $300 \mu \mathrm{mol} \mathrm{m} \mathrm{m}^{-2} \mathrm{~s}^{-1}$ and then decreased. In addition, the fits of attached EPS (Fig. 3F) were similar compared to the fraction of attached $\mathrm{C}$. The content of glucans in the C. closterium culture and the natural microphytobenthos samples (Fig. 3G) saturated at an
Table 3. Values of $\alpha^{\mathrm{B}}$ obtained from the curves of carbon fixation or excretion at different irradiances for Cylindrotheca closterium and the field samples

\begin{tabular}{|lcc|}
\hline & C. closterium & Field sample \\
\hline Total C & $0.019 \pm 0.010$ & $0.044 \pm 0.003$ \\
Intracellular C & $0.004 \pm 0.003$ & $0.006 \pm 0.001$ \\
Colloidal C & $0.004 \pm 0.001$ & $0.020 \pm 0.011$ \\
Colloidal EPS & $0.001 \pm 0.0003$ & $0.008 \pm 0.004$ \\
Attached C & $0.005 \pm 0.003$ & $0.012 \pm 0.005$ \\
Attached EPS & $0.002 \pm 0.001$ & $0.001 \pm 0.001$ \\
Glucan & $0.002 \pm 0.002$ & $0.001 \pm 0.0004$ \\
$\alpha^{\mathrm{B}}$ is the photosynthetic efficiency normalised to chlorophyll a \\
(chl a) $\left(\mathrm{mg} \mathrm{C}\left[\mathrm{mg} \mathrm{chl} \mathrm{a}^{-1} \mathrm{~h}^{-1}\left[\mathrm{mmol} \text { photons } \mathrm{m}^{-2} \mathrm{~s}^{-1}\right]^{-1}\right.\right.$ ) \\
\hline
\end{tabular}

irradiance of 100 and $150 \mu \mathrm{mol} \mathrm{m} \mathrm{m}^{-2} \mathrm{~s}^{-1}$, respectively, and remained constant in the saturating part of the curve. All fractions of both samples showed a significant positive relationship to irradiance (Spearman's rank test, $\mathrm{p} \leq 0.05)$.

The values for the initial slope $\left(\alpha^{\mathrm{B}}\right)$ obtained from the fits of the P/E curves give an indication of the efficiency of these processes at limiting light intensities. The values of the field samples were higher for total $C_{\text {, }}$ attached and colloidal C, and colloidal EPS (Table 3).

\section{Bacterial influence}

The sample contained $0.96 \mu \mathrm{g} \mathrm{ml}^{-1} \mathrm{chl} a$, and $9.8 \times 10^{5}$ bacteria $\mathrm{ml}^{-1}$ were counted. When assuming a C:chl a ratio of 50 (De Jonge 1980), the samples contained $48 \mu \mathrm{g} \mathrm{ml}^{-1}$ algal C. Using a C conversion factor of $2.0 \times$ $10^{-14} \mathrm{~g} \mathrm{C} \mathrm{cell}^{-1}$ (Lee \& Fuhrman 1987), bacterial C will account for $0.02 \mu \mathrm{g} \mathrm{ml}^{-1}$.

Maximum $C$ fixation was considerably higher in the sample with antibiotics compared to the sample without antibiotics $\left(P_{\text {max }}^{\mathrm{B}} 1.90\right.$ and $1.14 \mathrm{mgC}[\mathrm{mg} \mathrm{chl} \mathrm{a}]^{-1}$ $\left.\mathrm{h}^{-1}\right)$, respectively, but the initial slope of the P/E curve $\alpha^{\mathrm{B}}$ differed much less between both samples $(0.006$ and $\left.\left.0.008 \mathrm{mgC}^{2} \mathrm{mg} \mathrm{chl} \mathrm{a}\right]^{-1} \mathrm{~h}^{-1}\left[\mu \mathrm{mol} \mathrm{m} \mathrm{m}^{-2} \mathrm{~s}^{-1}\right]^{-1}\right)$. The light saturation parameter $E_{\mathrm{k}}$ was twice as high in the sample with antibiotics compared to the sample without (316 and $142 \mu \mathrm{mol} \mathrm{m} \mathrm{m}^{-2} \mathrm{~s}^{-1}$ ).

The addition of antibiotics resulted in higher values in almost all $\mathrm{C}$ fractions (Fig. 4A-F). The fitted curves of the different fractions of $\mathrm{C}$ showed comparable patterns between samples with and without antibiotics, with the exception of intracellular C (Fig. 4B). Mean percentages of EPS in the colloidal fractions were in the same range as those of the field sample of the other experiment (36 \pm 7 and $25 \pm 14 \%$ for colloidal EPS, and $11 \pm 9$ and $9 \pm 3 \%$ for attached EPS in the incubations without and with antibiotics, respectively). 

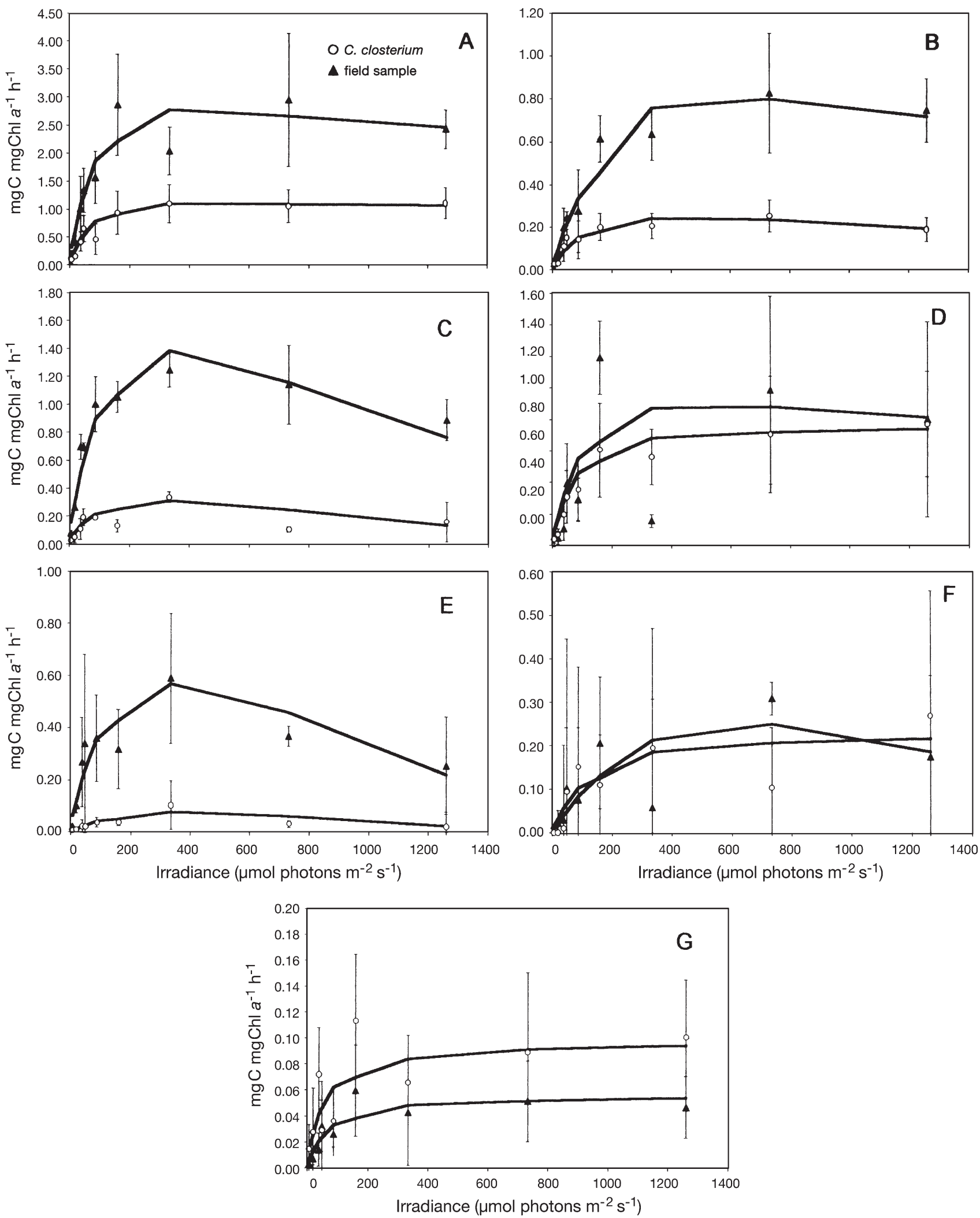

Fig. 3. Total carbon fixation (A) and partitioning in fractions of intracellular C (B), extracellular colloidal C (C) and EPS (E), extracellular attached C (D) and EPS (F), and glucans (G) at different irradiances by Cylindrotheca closterium (O) and a field sample of microphytobenthos ( $\mathbf{\Lambda})$ 
The efficiency of $\mathrm{C}$ fixation or EPS production $\left(\alpha^{\mathrm{B}}\right)$ did not show large difference between the samples with and without the addition of antibiotics from each other (Table 4 ). The $\alpha$ values were comparably high as the values of the comparison experiment between the culture and the field sample.
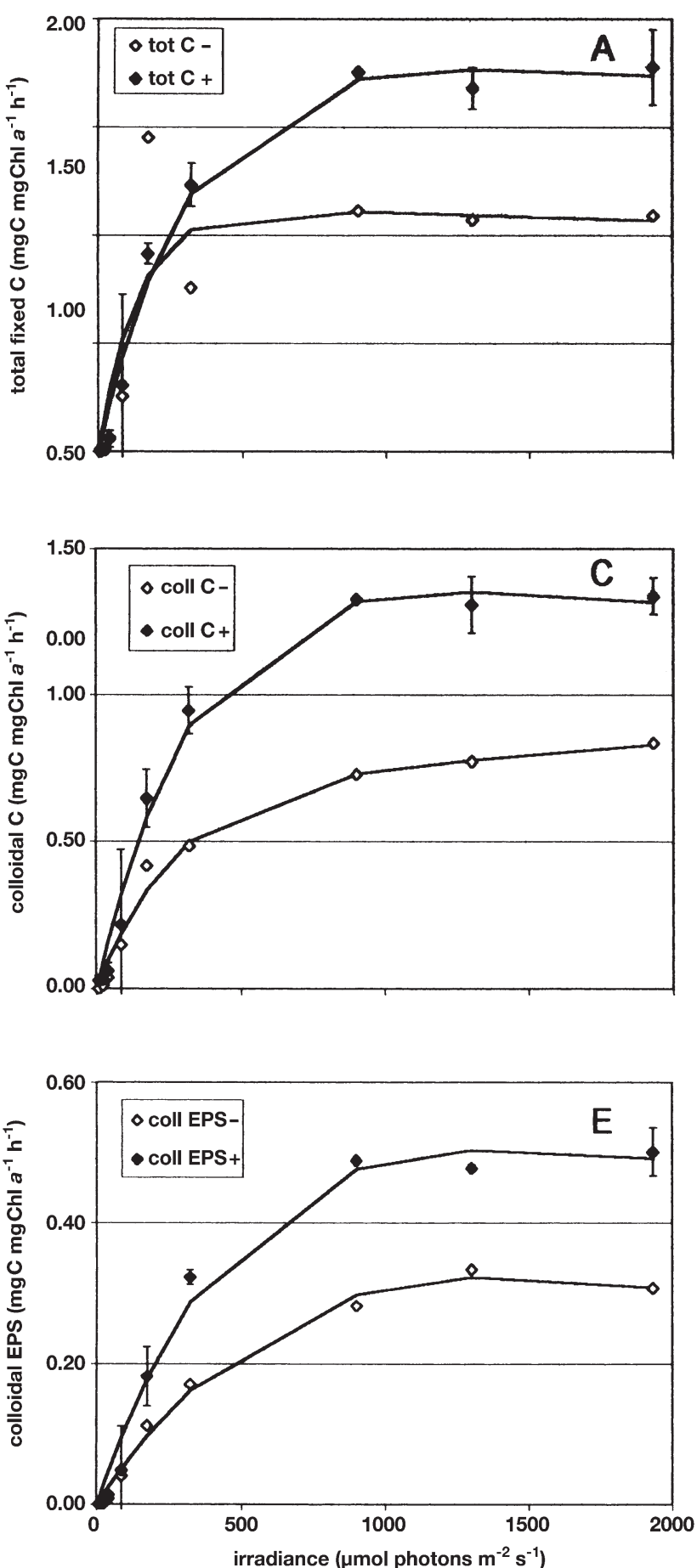

To check the inhibition effect of the antibiotics, D- ${ }^{14} \mathrm{C}$-glucose was added to another set of samples. The experiment showed that bacterial activity was successfully inhibited. This was demonstrated by a negligible ${ }^{14} \mathrm{C}$ incorporation (less than $1 \%$ of added ${ }^{14} \mathrm{C}$-glucose)
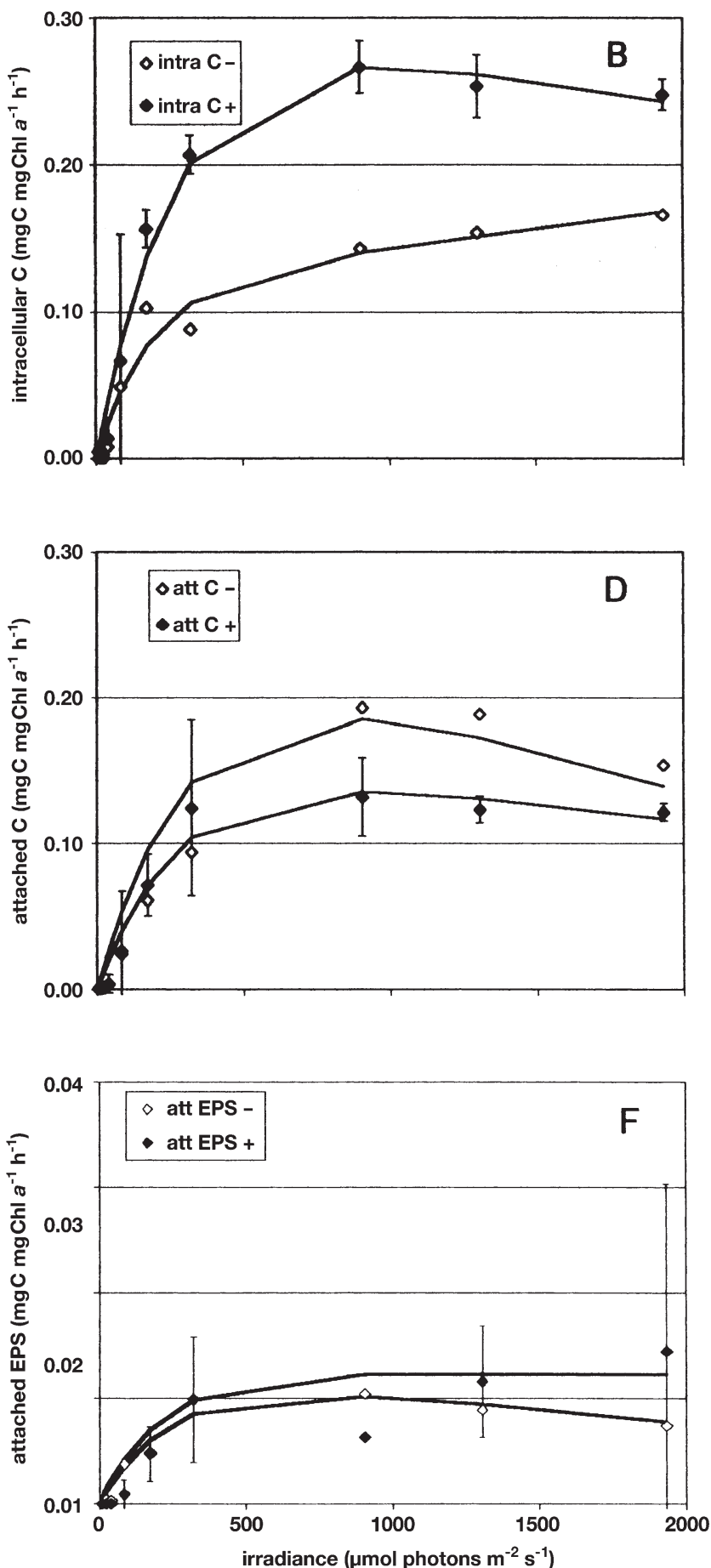

Fig. 4. Carbon fixation (A) and partitioning in intra- (B) and extracellular fractions (C to F) at different irradiances by a field sample of microphytobenthos with $(\diamond)$ and without $(\diamond)$ addition of antibiotics 
Table 4. Values of $\alpha^{\mathrm{B}}$ obtained from the curves of carbon fixation or excretion at different irradiances for field samples with and without addition of antibiotics

\begin{tabular}{|lcc|}
\hline & With antibiotics & Without antibiotics \\
\hline Total C & $0.006 \pm 0.0011$ & 0.008 \\
Intracellular C & $0.001 \pm 0.0001$ & 0.001 \\
Colloidal C & $0.004 \pm 0.0008$ & 0.002 \\
Colloidal EPS & $0.001 \pm 0.0003$ & 0.001 \\
Attached C & $0.001 \pm 0.0005$ & 0.001 \\
Attached EPS & $0.0001 \pm 0.00001$ & 0.0001 \\
$\alpha^{\mathrm{B}}$ is the photosynthetic efficiency normalised to chlorophyll a \\
$(\mathrm{chl} a)\left(\mathrm{mg} \mathrm{C}[\mathrm{mg} \mathrm{chl} a]^{-1} \mathrm{~h}^{-1}\left[\mu \mathrm{mol} \text { photons } \mathrm{m}^{-2} \mathrm{~s}^{-1}\right]^{-1}\right)$ \\
\hline
\end{tabular}

\section{DISCUSSION}

\section{Methodology}

The relative amount of total excreted $C$ (sum of colloidal and attached C) was similar to values reported by Goto et al. (1999). Smith \& Underwood (2000) found that up to $70 \%$ of the assimilated ${ }^{14} \mathrm{C}$ was present in the colloidal fraction. However, these authors only analysed the colloidal $\mathrm{C}$ fraction. Therefore, the values reported by Smith \& Underwood (2000) are high when compared to our results. Goto et al. (1999) found only about $3 \%$ of the fixed $\mathrm{C}$ in the colloidal $\mathrm{C}$ fractions of different diatom species and in a mixed microphytobenthos sample. In our study, the amounts of colloidal and attached $C$ varied between Cylindrotheca closterium and the field sample, as they did with irradiance. The discrepancy between our results and those of Goto et al. (1999) may be explained by the fact that these authors used GF/F filtration to separate algae and supernatant, whereas we used centrifugation. Glass-fiber filters are known to adsorb dissolved organic matter (Maske \& Garcia-Mendoza 1994) and therefore, the values of Goto et al. (1999) may be underestimated. Centrifugation, however, removes the fraction of colloidal C (De Brouwer et al. 2002).

Goto et al. (1999) found higher ${ }^{14} \mathrm{C}$ activity in the intracellular $\mathrm{C}$ fraction (26 to $57 \%$ ) when compared to our study. This difference might have been caused by the difference in incubation time, which was short compared to Goto et al. (1999). One possible reason might be that by using shorter incubation periods not all relevant pools of organic C were effectively labelled. To test whether the incubation time of 30 min was sufficient to detect the transfer of the photosynthetically fixed $\mathrm{C}$ into the different $\mathrm{C}$ pools, a preliminary experiment was carried out. Five different incubation times covering a range of 15 to 150 min were tested using a field sample, which was exposed to a constant irradiance of $200 \mu \mathrm{mol}$ photons $\mathrm{m}^{-2} \mathrm{~s}^{-1}$. The results for the different $\mathrm{C}$ fractions are shown in Table 5. Partitioning of the fixed $\mathrm{C}$ could already be detected after 15 min incubation. Therefore, we considered an incubation time of $30 \mathrm{~min}$ to be sufficient. The amount of $\mathrm{C}$ that was transferred to the different fractions was not constant over time. An increase in the relative amounts of $\mathrm{C}$ over time was observed for the colloidal and intracellular fractions, while the attached $\mathrm{C}$ fraction showed a concomitant decrease. Labelling of the glucan fraction was relatively constant.

The observed differences in relative $\mathrm{C}$ incorporation into the different fractions between the culture and the field sample could not be a result of the treatment, because all the samples were handled in a similar way. One explanation might be that the amount of stored or transferred $\mathrm{C}$ is species-specific (Goto et al. 1999, Staats et al. 1999). On the other hand, we cannot exclude some cell leakage due to the extraction method. Goto et al. (1999) also reported that a few intracellular components might have been released using $4 \mathrm{mM}$ EDTA for extraction. In an additional experiment, our extraction method was compared to others, such as an extraction with $1.5 \% \mathrm{NaCl}$, distilled water and $4 \mathrm{mM}$ EDTA. The cells were checked microscopically for membrane integrity by using the fluorescent marker DIBAC (De Brouwer et al. 2002). The percentages of DIBAClabelled cells did not significantly differ between the different treatments (except for $4 \mathrm{mM}$ EDTA), and measurements of glucan values obtained by the distilled water extraction were comparable to those obtained by a $1.5 \% \mathrm{NaCl}$ extraction, which would prevent osmotic stress for the algae.
Table 5. Carbon partitioning in different fractions of a field sample at different incubation times. Values are obtained at $200 \mu \mathrm{mol}$ photons $\mathrm{m}^{-2} \mathrm{~s}^{-1}$ and are normalised to chlorophyll a ( $\mathrm{chl}$ a) $\left(\mathrm{mg} \mathrm{C}[\mathrm{mg} \mathrm{chl} \mathrm{a}]^{-1} \mathrm{~h}^{-1}\right)$. Values in parentheses indicate the percentage of total incorporated $\mathrm{C}$ (sum of intracellular, colloidal and attached carbon)

\begin{tabular}{|cccccc|}
\hline $\begin{array}{c}\text { Incubation } \\
\text { time (min) }\end{array}$ & $\begin{array}{c}\text { Intracellular } \\
\text { C }\end{array}$ & $\begin{array}{c}\text { Colloidal } \\
\text { C }\end{array}$ & $\begin{array}{c}\text { Colloidal } \\
\text { EPS }\end{array}$ & $\begin{array}{c}\text { Attached } \\
\text { C }\end{array}$ & Glucan \\
\hline 15 & $0.54(26.6)$ & $0.95(46.8)$ & $0.37(18.2)$ & $0.54(26.6)$ & $0.03(2.0)$ \\
30 & $0.53(27.8)$ & $0.99(51.8)$ & $0.50(26.2)$ & $0.39(20.4)$ & $0.04(2.1)$ \\
60 & $0.79(32.5)$ & $1.20(49.8)$ & $0.65(26.8)$ & $0.44(18.1)$ & $0.05(2.1)$ \\
90 & $0.99(33.7)$ & $1.51(51.4)$ & $0.67(22.8)$ & $0.44(19.0)$ & $0.04(1.4)$ \\
150 & $0.75(35.4)$ & $1.28(60.4)$ & $0.98(46.2)$ & $0.09(4.2)$ & $0.04(1.9)$ \\
\hline
\end{tabular}




\section{Comparison between an axenic culture and a field sample}

To examine the effect of single environmental factors on excretion processes in benthic diatoms, only experiments with axenic cultures are useful. However, when natural communities are to be studied, bacteria are naturally present. Therefore, a comparison between results obtained by an axenic laboratory culture and by a sample collected from the field is difficult. In the literature, examples of such comparisons have been described (Smith \& Underwood 1998, Staats et al. 2000 b). However, in these studies, the laboratory culture and the field sample were treated differently. In our study, the field samples were kept under exactly the same conditions as the culture $1 \mathrm{~d}$ before the experiment started and during the experiment. Nevertheless, the history of the cells was different. Cylindrotheca closterium was grown on sand and in liquid medium under constant light and temperature conditions, while the natural community experienced varying field conditions and subsequent treatment when isolated from the sediment. Notwithstanding the different histories, the total amount of irradiance did not differ much between the culture and the field sample during the $10 \mathrm{~d}$ preceding the experiment. The culture received a total irradiance of $4.3 \mathrm{~mol} \mathrm{~m}^{-2}$ during preincubation, whereas this was $5.0 \mathrm{~mol} \mathrm{~m}^{-2}$ for the field sample (height of the station and tidal effects were included in the calculations) before it was taken. Although the total dose of irradiance was more or less similar for the 2 samples, they experienced large differences in the duration of light or darkness as well as in the maximum irradiance and other environmental conditions, such as changes in salinity or changes in nutrient conditions.

The second important difference was the presence or absence of bacteria in the algal suspensions. In the Cylindrotheca closterium culture, bacteria were absent, whereas the field sample contained about $9.8 \times 10^{5}$ bacterial cells ml${ }^{-1}$. This is a low number compared to natural sediment, which may contain 6 to $8 \times 10^{9}$ bacterial cells $\mathrm{cm}^{-3}$ wet natural sediment (Van Duyl et al. 1999) or $10^{9}$ bacteria $\mathrm{ml}^{-1}$ in pore water (Schmidt et al. 1998). Bacteria may affect the amount of $C$ and EPS in the sample because they are able to produce as well as to decompose EPS (Cole et al. 1988, Decho 1990). To assess the influence of bacteria, an experiment was conducted in which antibiotics were added that successfully inhibited bacterial activity. This was demonstrated by the very low ${ }^{14} \mathrm{C}$ incorporation (less than $1 \%$ from added ${ }^{14} \mathrm{C}$-glucose). This is low in comparison with Goto et al. (1999) who considered an uptake of $4 \%$ of the added ${ }^{14} \mathrm{C}$-glucose as negligible. Therefore, results of the field sample treated with antibiotics may be considered as true algal excretion. Jensen (1984) showed that algae may react highly sensitively to the addition of most antibiotics. However, our results indicated that there was no obvious difference in the efficiency of $C$ fixation $\left(\alpha^{\mathrm{B}}\right)$ between the sample with and without addition of antibiotics. This was taken as evidence that photosynthesis or $\mathrm{C}$ fixation by the algae was not affected by the addition of antibiotics. Furthermore, we used a lower concentration of streptomycin than Goto et al. (1999) who stated that the algae used in their experiment were unaffected by the antibiotics. However, we observed higher $\mathrm{C}$ incorporation in the fractions of total $\mathrm{C}$, intracellular $\mathrm{C}$, colloidal $\mathrm{C}$ and EPS in the samples treated with antibiotics.

Algal and bacterial $\mathrm{C}$ were calculated in order to check whether this difference in the results of the experiments with and without addition of antibiotics could be explained by bacterial use of the $\mathrm{C}$ and its subsequent mineralisation to $\mathrm{CO}_{2}$. However, this explanation was rejected because bacterial biomass accounted for only $0.04 \%$ of the algal C. Moreover, it would also not explain why the intracellular fixed $\mathrm{C}$ is much higher in the presence of antibiotics. So far, the results do not suggest a role of the associated bacteria in the elevated $\mathrm{C}$ fixation, but it seems more likely that the antibiotics directly affect the algal metabolism. For instance, it can be speculated that the antibiotics specifically inhibit mitochondrial respiration, preventing any loss of recently fixed C. Unfortunately, we did not check the effect of antibiotics on the axenic culture and hence, we are currently unable to explain the observed results.

The amount of $\mathrm{C}$ that was excreted, relative to photosynthetically fixed $\mathrm{C}$, was similar between the culture and the field samples. Two different types of extracellular C and EPS (attached and colloidal) were analysed which are known to differ in terms of localisation, production dynamics and composition (Staats et al. 1999, De Brouwer \& Stal 2002, De Brouwer et al. 2002). So far, several hypotheses exist on the mechanisms or factors that control the production of the different fractions of EPS (Staats et al. 1999, 2000a,b, Smith \& Underwood 2000). Most recently, De Brouwer \& Stal (2002) suggested that attached EPS is produced as a result of overflow metabolism due to limited internal storage capacity, and that the production of colloidal EPS is related to the process of migration. The contribution of attached and colloidal $\mathrm{C}$ to the total extracellular $\mathrm{C}$ pool differed between the culture and the field sample, which can have several explanations. One reason for this may be that the separation between both fractions is operational. In reality, the transition between these 2 fractions could be less strict. Another reason for the higher amount of colloidal C in the field sample may be that the algae freshly iso- 
lated from the field still have their ability to migrate, whereas this ability could have been much less distinct in Cylindrotheca closterium, which was kept in culture for a long time. Furthermore, the production of these types of extracellular $\mathrm{C}$ depends on the physiological status of the organism, which may explain the distinction between the field and the culture samples. In the field sample, slightly more $\mathrm{C}$ was incorporated in the EPS fractions compared to the culture. The amounts of EPS that are excreted may differ between algal species as a consequence of differences in photosynthetic and EPS production capacities (Smith \& Underwood 1998, Goto et al. 1999). Moreover, the algae from the field were not in a defined growth stage as was the case for C. closterium, and the amount of produced EPS is obviously dependent of the physiological state and growth phase of the culture (Staats et al. 1999). Considering that the algae, after being separated from the sediment, were resuspended in fresh medium (i.e. favourable growth conditions), we assume that the algae have been in the exponential phase when the experiment started. Another reason for the deviation between the 2 samples may be the relation of absolute EPS to the chl a content, which varies depending on the species and the physiological state of the cells (De Jonge 1980, Davidson 1991).

The differences between the culture and the field sample in the initial slope $(\alpha)$ of the P/E curves are difficult to interpret. There might be a higher capacity of the field sample in $\mathrm{C}$ fixation and production of exopolymers, but this may be the result of differences in species composition, growth status or light history. Notwithstanding these differences, the percentages of attached and colloidal EPS were constant over the range of irradiances measured. This means that the production of EPS is directly dependent on the rate of photosynthesis.

\section{Conclusions and ecological implications}

Although some differences between a laboratory culture and a sample from the field were observed, the relative amount of total excreted $\mathrm{C}$ (the sum of colloidal and attached C) as well as the percentages of EPS in these fractions were comparable between an axenic culture of Cylindrotheca closterium and a field sample. Photosynthetically fixed $\mathrm{C}$ was excreted within a period of $30 \mathrm{~min}$, even under low light conditions (less than $10 \mu \mathrm{mol} \mathrm{m}{ }^{-2} \mathrm{~s}^{-1}$ ). The percentage of excreted $\mathrm{C}$ relative to total fixed $\mathrm{C}$ was constant for C. Closterium, while it changed only slightly at higher irradiances in the natural microphytobenthos. This suggests that photosynthetic overflow as a result of nutrient limitation (Staats et al. 1999) did not apply in these experiments. Additionally, nutrient limitation is not very likely for the field sample collected in the nutrient-rich Westerschelde. The production of extracellular material was directly dependent on photosynthetic rates, which corroborates the findings of Smith \& Underwood (2000) and Staats et al. (2000b).

Staats et al. (2000b) observed that a certain light limit is required before secretion starts, but in contrast to this observation, Smith \& Underwood (2000) reported an elevated production of exopolymers in the dark. However, in our study only $5 \%$ of the colloidal C that was produced at the lowest irradiance $\left(5 \mu \mathrm{mol} \mathrm{m}{ }^{-2}\right.$ $\mathrm{s}^{-1}$ ) by Cylindrotheca closterium was measured in the dark, but no attached material was detected. The amount of provided light clearly affected the quantity of extracellular C.

The results obtained indicate a relationship between irradiance and the amount of extracellular carbohydrates excreted. This means that in the field, a seasonal influence on the production of exopolymers may be expected, e.g. high irradiances in spring or summer cause higher production rates.

Acknowledgements. We would like to thank Jan Peene for technical assistance and Jacco Kromkamp for valuable comments on the manuscript. This work was financially supported by the European project MAS3-CT98-0166-Climerod. This is publication 3011 of the Netherlands Institute of Ecology (NIOO-CEME).

\section{LITERATURE CITED}

Cole JJ, Findlay S, Pace ML (1988) Bacterial production in fresh and saltwater ecosystems: a cross-system overview. Mar Ecol Prog Ser 43:1-10

Davidson IR (1991) Environmental effects on algal photosynthesis: temperature. J Phycol 27:2-8

De Brouwer JFC, Stal LJ (2002) Daily fluctuations of exopolymers in cultures of the benthic diatoms Cylindrotheca closterium and Nitzschia sp. (Bacillariophyceae). J Phycol 38:464-472

De Brouwer JFC, Bjelic S, de Deckere, EMGT, Stal LJ (2000) Interplay between biology and sedimentology in a mudflat (Biezelingse Ham, Westerschelde, The Netherlands). Cont Shelf Res 20:1159-1178

De Brouwer JFC, Wolfstein K, Stal LJ (2002) Physical characterization and diel dynamics of different fractions of extracellular polysaccharides in an axenic culture of a benthic diatom. Eur J Phycol 37:37-44

Decho AW (1990) Microbial exopolymer secretions in ocean environments: their role(s) in food webs and marine processes. Oceanogr Mar Biol Annu Rev 28:73-153

De Jonge VN (1980) Fluctuations in the organic carbon to chlorophyll a ratios for estuarine benthic diatom populations. Mar Ecol Prog Ser 2:345-353

Goto N, Kawamura T, Mitamura O, Terai H (1999) Importance of extracellular organic carbon production in the total primary production by tidal-flat diatoms in comparison to phytoplankton. Mar Ecol Prog Ser 190:289-295

Goto N, Mitamura O, Terai H (2001) Biodegradation of photo- 
synthetically produced extracellular organic carbon from intertidal benthic algae. J Exp Mar Biol Ecol 257:73-86

Hasle GR, Fryxell GA (1970) Diatoms: cleaning and mounting for light and electron microscopy. Trans Am Microsc Soc 89:469-474

Hoagland KD, Rosowski JR, Gretz MR, Roemer SC (1993) Diatom extracellular polymeric substances: function, fine structure, chemistry and physiology. J Phycol 29:537-566

Jeffrey SW, Humphrey GF (1975) New spectrophotometric equation for determining chlorophylls $a, b, c 1$ and $c 2$ in higher plants, algae and natural phytoplankton. Biochem Physiol Pflanz 167:191-194

Jensen LM (1984) Antimicrobial action of antibiotics on bacterial and algal carbon metabolism: on the use of antibiotics to estimate bacterial uptake of algal extracellular products (EOC). Arch Hydrobiol 99:423-432

Lee S, Fuhrman JA (1987) Relationships between biovolume and biomass of naturally derived marine bacterioplankton. Appl Environ Microbiol 53:1298-1303

Lewis MR, Smith JC (1983) A small volume, short-incubation time method for measurement of photosynthesis as a function of incident irradiance. Mar Ecol Prog Ser 13:99-102

Maske H, Garcia-Mendoza E (1994) Adsorption of dissolved organic matter to the inorganic filter substrate and its implications for ${ }^{14} \mathrm{C}$ uptake measurements. Appl Environ Microbiol 60:3887-3889

Parsons TR, Maita Y, Lalli CM (1984) A manual of chemical and biological methods for seawater analysis. Pergamon Press, Oxford

Paterson DM (1989) Short-term changes in the erodibility of intertidal cohesive sediments related to the migratory behaviour of epipelic diatoms. Limnol Oceanogr 34:223-234

Schmidt JL, Deming JW, Jumars PA, Keil RG (1998) Constancy of bacterial abundance in surficial marine sediments. Limnol Oceanogr 43:976-982

Smith DJ, Underwood GJC (1998) Exopolymer production by intertidal epipelic diatoms. Limnol Oceanogr 43: 1578-1591

Smith DJ, Underwood GJC (2000) The production of extracel-

Editorial responsibility: Otto Kinne (Editor),

Oldendorf/Luhe, Germany lular carbohydrates by estuarine benthic diatoms: the effect of growth phase and light and dark treatment. J Phycol 36:321-333

Staats N, De Winder B, Stal LJ, Mur LR (1999) Isolation and characterization of extracellular polysaccharides from the epipelic diatoms Cylindrotheca closterium and Navicula salinarum. Eur J Phycol 34:161-169

Staats N, Stal LJ, Mur LR (2000a) Exopolysaccharide production by the epipelic diatom Cylindrotheca closterium: effects of nutrient conditions. J Exp Mar Biol Ecol 249:13-27

Staats N, Stal LJ, de Winder B, Mur LR (2000b) Oxygenic photosynthesis as driving process in exopolysaccharide production of benthic diatoms. Mar Ecol Prog Ser 193: 261-269

Sutherland TF, Grant J, Amos CL (1998) The effect of carbohydrate production by the diatom Nitzschia curvelineata on the erodibility of sediment. Limnol Oceanogr 43:65-72

Underwood GJC (1994) Seasonal and spatial variation in epipelic diatom assemblages in the Severn estuary. Diatom Res 9:451-472

Underwood GJC, Kromkamp JC (1999) Primary production by phytoplankton and microphytobenthos in estuaries. Adv Ecol Res 29:93-153

Van Duyl FC, De Winder B, Kop AJ, Wollenzien UIA (1999) Tidal coupling between carbohydrate concentrations and bacterial activities in diatom-inhabited intertidal mudflats. Mar Ecol Prog Ser 191:19-32

Van Liere L, Walsby AE (1982) Interactions of cyanobacteria with light. In: Carr NG, Whitton BH (eds) The biology of cyanobacteria. Blackwell Science Publishers, Oxford, p 9-45

Walsby AE (1997) Numerical integration of phytoplankton photosynthesis through time and depth in a water column. New Phytol 136:189-209

Weinbauer MG, Beckmann C, Höfle MG (1998) Utility of green fluorescent nucleic acid dyes and aluminium oxide membrane filters for rapid epifluorescence enumeration of soil and sediment bacteria. Appl Environ Microbiol 64: 5000-5003

Submitted: February 2, 2002; Accepted: July 4, 2002

Proofs received from author(s): December 2, 2002 